\title{
Hubungan Motivasi Petani dalam Berusahatani Sayur-mayur dengan Keterlibatannya pada Kegiatan Peken Carik di Subak Sembung, Kelurahan Peguyangan, Kecamatan Denpasar Utara
}

\author{
NI LUH GEDE NIRMALA DEVI, I DEWA GEDE RAKA SARJANA, \\ WAYAN SUDARTA
}

Program Studi Agribisnis, Fakultas Pertanian, Universitas Udayana

Jln. PB. Sudirman Denpasar 80323

Email: nirmalaadevi09@gmail.com

idewagederakasarjana@yahoo.com

\begin{abstract}
Correlation of Farmers Motivation to Cultivate Vegetables with Their Involvement atPeken Carik Activity in Subak Sembung, Peguyangan Village, North Denpasar Sub-district
\end{abstract}

Vegetables are one of the horticultural sub-sector plants which is amount cultivated bylots of farmers, one of them is farmers in Subak Sembung, Peguyangan Village, North Denpasar Sub-district. Subak Sembung developed into an ecotourism and has a supporting program known as peken carik activity. All of farmers in Subak Sembung are involved at peken carik activity and make it as an shopping tour media to sell vegetables to people which is in line with their motivation to cultivate vegetables. This research aims to determine the level of farmers motivation to cultivate vegetables, the level of farmers involvement at peken carik activity, and correlation between the farmers motivation to cultivate vegetables with their involvement at peken carik activity in Subak Sembung, Peguyangan Village, North Denpasar Sub-district. Sampling are 60 respondent using incidental method. The data were analyzed used qualitative analysis and quantitative analysis of Spearman rank correlation test.The result of qualitative analysis to describe the level of farmers motivation to cultivate vegetables was in high category, however the level of farmers involvement at peken carik activity was in very low category. The result of Spearman rank correlation test showed the correlation of farmer motivation to cultivate vegetables with their involvement at peken carik activity in Subak Sembung, Peguyangan Village, North Denpasar Sub-districtwas in low category.

Keywords: motivation, involvement, peken carik activity

\section{Pendahuluan}

\subsection{Latar Belakang Masalah}

Sub sektor hortikultura memiliki komoditiyang cukup potensial untuk dikembangkan secara agribisnis, bahkan subsektor ini merupakan salah satu sub sektor 
yang berperansebagai penyumbang devisa negara karena memiliki nilai ekonomi dan nilai tambah yang cukup tinggi (Hanafile, 2010). Menurut Marsadi (2010), salah satu tanaman sub sektor hortikultura yang cukup potensial dikembangkan adalah sayurmayur. Berdasarkan data BPS Provinsi Bali (2017), tanaman sayur-mayur yang dominan diusahakan oleh petani di Kota Denpasar adalah jenis tanaman sayur-mayur semusim seperti sawi, bayam dan kangkung.Petani di Kota Denpasar banyak mengusahakan tanaman sayur-mayur, salah satunya adalah petani di Subak Sembung.Sejumlah petani di Subak Sembung yakni $75 \%$ dari total petani yang ada, melakukan usahatani sayur-mayur. Produksi hortikultura khususnya sayur-mayur tentunya didasari dengan dorongandari petani untuk mengusahatanikannya (Restutiningsih, 2016).Terlihat dari banyaknya petani di Subak Sembung yang berusahatani sayur-mayur, tentunya petani memiliki motivasi tertentu.Motivasidapat bersumber dari dalam diri petani maupun lingkungan luar petani (Winardi, 2002).

Subak Sembung akhirnya dikembangkan menjadi kawasan ekowisata pada November 2015dan dibuat program penunjang pengembangan ekowisata yang dapat menarik masyarakat untuk berkunjung.Program tersebut berupa kegiatan pasar tani yang diistilahkan sebagai peken carik.Kegiatan tersebut dijadikan sebagai upaya pemberdayaan petani di Subak Sembung untuk memutus rantai pasok pasar, serta sebagai media wisata belanja bagi masyarakat karena harga sayur-mayur yang dijual petani cukup murah dibandingkan dengan harga di pasar.Tujuannya agar masyarakat membeli sayur-mayur secara langsung dari petani.Para petani di Subak Sembung juga menjadikan kegiatan peken carik sebagai peluang untuk mempromosikan sayur-mayur yang mereka hasilkan kepada masyarakat luas.Besarnya peluang bagi petani dari adanya kegiatan peken carik, sejalan dengan motivasi yang dimiliki petani dalam berusahatani sayur-mayur sehingga petani pun terlibat pada kegiatan tersebut.Hadirnya kegiatan peken carik dijadikan sebagai langkah bagi petani di Subak Sembung untuk memperoleh tambahan penghasilandari hasil penjualan sayur-mayur demi memenuhi kebutuhan hidup.Berdasarkan uraian tersebut, menarik untuk dikaji hubungan antara motivasi petani dalam berusahatani sayur-mayur dengan adanya keterlibatannya pada kegiatan peken carik di Subak Sembung, Kelurahan Peguyangan, Kecamatan Denpasar Utara.

\subsection{Rumusan Masalah}

Berdasarkan uraian latar belakang masalah di atas, maka rumusan masalah dalampenelitian ini sebagai berikut.

1. Bagaimana tingkat motivasi petanidalam berusahatani sayur-mayur di Subak Sembung, Kelurahan Peguyangan, Kecamatan Denpasar Utara?

2. Bagaimana tingkat keterlibatan petani pada kegiatan peken carik di Subak Sembung, Kelurahan Peguyangan, Kecamatan Denpasar Utara?

3. Bagaimana hubungan motivasi petani dalam berusahatani sayur-mayur dengan keterlibatannya pada kegiatan peken carik di Subak Sembung, Kelurahan Peguyangan, Kecamatan Denpasar Utara?

\subsection{Tujuan Penelitian}

Tujuan yang ingin dicapai dalam penelitian ini sebagai berikut.

1. Mengetahui tingkat motivasi petani dalam berusahatani sayur-mayur di Subak Sembung, Kelurahan Peguyangan, Kecamatan Denpasar Utara. 
2. Mengetahui tingkat keterlibatan petani pada kegiatan peken carikdi Subak Sembung, Kelurahan Peguyangan, Kecamatan Denpasar Utara.

3. Mengetahui hubungan motivasi petani dalam berusahatani sayur-mayur dengan keterlibatannya pada kegiatan peken carik di Subak Sembung, Kelurahan Peguyangan, Kecamatan Denpasar Utara.

\section{Metode Penelitian}

\subsection{Lokasi dan Waktu Penelitian}

Penelitian ini dilaksanakan di Subak Sembung, Kelurahan Peguyangan, Kecamatan Denpasar Utara dengan pemilihan lokasi secarapurposive (sengaja).Pelaksanaan penelitian dimulaidari Desember 2017 sampai dengan Mei 2018.

\subsection{Data Penelitian}

Sumber data terdiri atas data primer dan data sekunder, sedangkan jenis data yang digunakan dalam penelitian ini meliputi data kuantitatif dan data kualitatif.Data primer meliputi hasilwawancara menggunakankuesioner dengan responden terkait persepsi mengenai motivasi petani dalam berusahatani sayur-mayur dan keterlibatannya pada kegiatan peken carik.Data sekunder meliputi profil dan struktur kepengurusan subak yang bersumber dari Pekaseh Subak Sembung, serta profil Kelurahan Peguyanganyang bersumber dari Lurah dan BPS.Data kualitatif menjelaskan mengenai gambaran umum lokasi penelitian, karakteristik responden, dan alasandari persepsi responden mengenaimotivasi petani dalam berusahatani sayur-mayur dan keterlibatannya pada kegiatan peken carik.Data kuantitatif berupa data jumlah petani, data luas wilayah penelitian, dan data luas penggunaan lahan masing-masing petani di Subak Sembung.

\subsection{Metode Pengumpulan Data}

Metode pengumpulan data yang digunakan dalam penelitian ini yaitusurvei, wawancara, dan dokumentasi.Survei yaitu metode pengumpulan datamenggunakan kuesioner sebagai alat pengumpulan data pokok (Retno, 2010). Wawancara adalah pertemuan dua orang untuk bertukar informasi melalui tanya jawab. Wawancara dilakukan untuk mendapatinformasi tambahan secara langsung dari responden.Dokumentasi merupakan catatan peristiwa yang telah berlalu(Sugiyono, 2011).Dokumentasi digunakanuntuk mengulang kembali informasi yang telah dikumpulkan serta melengkapi data penelitian.

\subsection{Populasi dan Sampel Penelitian}

Populasi dalam penelitian ini adalah petani yang berusahatani sayur-mayur di Subak Sembung yang berjumlah sekitar 148 orang.Pengambilan sampel penelitian menggunakan rumus Slovin dengan nilai batas toleransi kesalahan 10\%, sehingga didapatkan sampel sebanyak 60 orang dengan teknik incidentalsampling, artinya siapa pun petani sayur-mayur yang ditemui peneliti akan dijadikan sampel penelitian.

\subsection{Variabel dan Analisis Data}

Variabel operasional adalah variabel yang secara nyata terdapat dalam lingkup objek penelitian. Variabel operasional penelitian ini meliputi motivasi intrinsik petani, motivasi ekstrinsik petani, dan tingkat keterlibatan petani.Setiap variabel diukur dengan beberapa indikator yang secara terperinci dijabarkanmelalui parameter tertentu dan menggunakan pengukuran skor berjenjang lima dengan preferensi penilaian tertentu. 
Analisis data merupakan proses mengatur urutan data, mengorganisasikanya ke dalam suatu pola, kategori, dan satuan uraian dasar yang digunakan untuk menjawab masalah yang berkaitan dengan kegiatan penelitian. Analisis data yang digunakan meliputikualitatif dan kuantitatif yaitu uji korelasi rank Spearman. Data yang diperoleh dihitung dengan bantuan skoring.Skor 1 merupakan skor minimum dan skor 5 merupakan skor maksimum.Data hasil pengukuran baik tingkat motivasi petani maupun tingkat keterlibatan petani didistribusikan ke dalam lima kelas menggunakan rumus interval kelas sebesar 0,8 yaitu skor 1 s.d 1,8 kategori sangat rendah, skor >1,8 s.d 2,6 kategori rendah, skor $>2,6$ s.d 3,4 kategori sedang, skor $>3,4$ s.d 4,2 kategori tinggi dan skor $>4,2$ s.d 5 kategori sangat tinggi. Mengukur hubungan antara tingkat motivasi petani dalam berusahatani sayur-mayur dengan tingkat keterlibatan petani pada kegiatan peken carik di Subak Sembung dapat menggunakan pedoman kategori untuk interpretasi koefisien korelasi sesuai Tabel 1.

Tabel 1.

Interpretasi Koefisien Korelasi

\begin{tabular}{cc}
\hline Interval Koefisien & Tingkat Hubungan \\
\hline $0,00-0,19$ & Sangat Rendah \\
$0,20-0,39$ & Rendah \\
$0,40-0,59$ & Sedang \\
$0,60-0,79$ & Kuat \\
$0,80-1,00$ & Sangat Kuat \\
\hline
\end{tabular}

Sumber:Sugiyono, 2011

\section{Hasil dan Pembahasan}

\subsection{Karakteristik Responden}

Karakterisktik responden dalam penelitian ini akan dijelaskan sebagai berikut.

1. Umur

Umur dapat dijadikan ukuran untuk melihat kemampuan seseorang dalam melakukan pekerjaan. Berdasarkan data yang diperoleh, keseluruhan responden memiliki rentang umur antara $31-75$ tahun dengan rata-rata umur yaitu 52,9 tahun. Mayoritas responden memiliki rentang umur 46 - 60 tahun yang termasuk kategori tua, sesuai kategori umur menurut WHO dan Bee (dalam Padila, 2013).

2. Jenis kelamin

Jenis kelamin adalah identitas seksual yang melekat pada diri seseorang.Berdasarkan data yang diperoleh, responden yang berjenis kelamin laki-laki sebanyak 57 orang dan perempuan sebanyak tiga orang.

3. Pendidikan formal

Pendidikan formal merupakan jenjang pendidikan yang telah ditempuh seseorang secara formal di sekolah.Pendidikan juga sebagai proses belajar bagi petani untuk meningkatkan taraf hidup (Manyamsari, 2014). Rentang pendidikan formalresponden antara $0-12$ tahun dengan rata-rata selama 8,25 tahun. Mayoritas responden memiliki riwayat pendidikan formal selama1 - 9 tahun, dalam hal ini 23 responden telah menamatkan pendidikan di bangku SD atau sederajat, dan 17 responden telah menamatkan pendidikan di bangku SMP atau sederajat.

4. Luas lahan garapan

Luas lahan garapan merupakan jumlah seluruh lahan sawah yang diusahakan responden.Kisaran luas lahan responden antara $<50-100$ are. Mayoritas 
responden memiliki kisaran luas lahan antara 5-67 aredengan rata-rata luas lahan garapan keseluruhan seluas 27,95 are.Kategori luas lahan garapan responden termasuk kategori kecil menurut Sayogyo (dalam Susilowati, 2012).

5. Pengalaman berusahatani

Pengalaman berusahatani merupakan lamanya petani melakukan usahatani sayurmayur. Rata-rata pengalaman berusahatani yang dimiliki responden selama 13,45 tahun dengan kisaran antara 5 - 34tahun. Sebagian besar responden memiliki pengalaman berusahatani $>10$ tahun yang termasuk kategori berpengalaman menurut Soeharjo dan Patong (dalam Perdana, 2016).

6. Jumlah anggota rumah tangga

Jumlah anggota rumah tangga merupakan jumlah seluruh anggota yang tinggal bersama dan tergabung dalam satu unit angaran belanja. Berdasarkan data yang diperoleh, responden memiliki jumlah anggota rumah tangga antara dua sampai lebih darilima orang. Sebagian besar responden memiliki jumlah anggota rumah tangga sebanyak empat sampai lima orang.

\subsection{Motivasi Petani dalam Berusahatani Sayur-mayur}

Kondisi yang mendorong seseorang untuk melakukan aktivitas tertentu demi pencapaian tujuan disebut motivasi.Motivasi dalam penelitian ini meliputi motivasi intrinsik dan motivasi ekstrinsik. Tingkat motivasi petani dalam berusahatani sayurmayur dapat dilihat pada Tabel 2.

Tabel 2.

Tingkat Motivasi Petani dalam Berusahatani Sayur-mayur di Subak Sembung, Kelurahan Peguyangan, Kecamatan Denpasar Utara, Tahun 2018

\begin{tabular}{clcc}
\hline No. & Variabel sumber motivasi & Rata-rata pencapaian skor & Kategori \\
\hline 1. & Motivasi intrinsik & 3,44 & Tinggi \\
2. & Motivasi ekstrinsik & 3,58 & Tinggi \\
\hline & Tingkat motivasi petani & 3,51 & Tinggi \\
\hline
\end{tabular}

Sumber: Data primer diolah, 2018

Tabel 2 menunjukan hasil penelitian mengenai tingkat motivasi petanidalam berusahatani sayur-mayur di Subak Sembung Kelurahan Peguyangan, Kecamatan Denpasar Utara. Tingkat motivasi petani dalam berusahatani sayur-mayur termasuk kategori tinggi denganrata-rata pencapaian skor 3,51.

Tingkat motivasi intrinsik petani dalam berusahatani sayur-mayur di Subak Sembung, Kelurahan Peguyangan, Kecamatan Denpasar Utara termasuk kategori tinggi dengan rata-rata pencapaian skor 3,44. Tingkat motivasi petani jika dilihat dari pencapaian skor motivasi intrinsik menandakan bahwa adanya dorongan yang besar bagi petani dalamberusahatani sayur-mayur untuk memenuhi kebutuhan hidup mereka saat ini dan berupaya mendapatkan penghasilan yang lebih besar.Motivasi intrinsik petani diukur dari beberapa pemenuhan kebutuhan seperti kebutuhan fisiologis, kebutuhan keamanan, kebutuhan sosial, dan kebutuhan akan penghargaan, sedangkan kebutuhan aktualisasi diri tidak dibahas dalam penelitian ini karena petani di Subak Sembung memprioritaskan untuk memenuhi tingkatan kebutuhan yang lebih tinggi atau empat tingkatan kebutuhan sebelumnya. Motivasi intrinsik terbesar petani berasal dari kebutuhan akan penghargaan. 
Tingkat motivasi ekstrinsik petani dalam melakukan usahatani sayur-mayur di Subak Sembung, Kelurahan Peguyangan, Kecamatan Denpasar Utara termasuk kategori tinggi denganrata-rata pencapaian skor 3,58. Tingginya tingkat motivasi ekstrinsik petani menandakan besarnya dorongan dari orang lain (luar diri petani) untuk berusahatani sayur-mayur. Dorongan tersebut berasal dari kelompok tani, pengunjung subak, pengelola ekowisata dan PPL.Tingkat motivasi ekstrinsik lebih besar daripada tingkat motivasi intrisnik karena besarnya dorongan dari luar diri petani seperti keinginan agar sayur-mayur petani dihargai oleh masyarakat yang sejalan dengan dukungan dari pengelola ekowisata dan pengunjung subak melalui kegiatan peken carik.

\subsection{Keterlibatan Petani pada Kegiatan Peken Carik}

Keterlibatan merupakan keikutsertaan seseorang karena adanya suatu hal yang ingin dicapai.Keterlibatan petani dalam mengikuti kegiatan peken carik di Subak Sembung dilihat dari frekuensi petani dalammengikuti kegiatan.Tingkat keterlibatan petani pada kegiatan peken carikdapat dilihat pada Tabel 3.

\section{Tabel 3.}

Tingkat Keterlibatan Petani pada Kegiatan Peken Carik di Subak Sembung, Kelurahan Peguyangan, Kecamatan Denpasar Utara, Tahun 2018

\begin{tabular}{rlcc}
\hline No. & Parameter tingkat keterlibatan petani & $\begin{array}{c}\text { Rata-rata } \\
\text { pencapaian skor }\end{array}$ & Kategori \\
\hline 1. & $\begin{array}{l}\text { Keaktifan mengikuti kegiatan untuk } \\
\text { promosi hasil usahatani }\end{array}$ & 1,17 & Sangat rendah \\
2. & $\begin{array}{l}\text { Keaktifan mengikuti kegiatan karena } \\
\text { memiliki waktu }\end{array}$ & 1,10 & Sangat rendah \\
3. & $\begin{array}{l}\text { Keaktifan mengikuti kegiatan karena } \\
\text { memiliki kelebihan hasil panen }\end{array}$ & 1,08 & Sangat rendah \\
\hline & Tingkat keterlibatan petani & 1,11 & Sangat rendah \\
\hline
\end{tabular}

Tabel 3 menunjukkan bahwa tingkat keterlibatan petani yang termasuk kategori sangat rendahmemiliki pencapaian skor rata-rata 1,11. Hal tersebut menunjukkan bahwa rendahnya keterlibatan petanipada kegiatan peken carikyang dilihat dari frekuensi mengikuti kegiatan menandakan mayoritas petani tidak pernah hadir pada saat kegiatan peken carikdiadakan.Frekuensi petani mengikuti kegiatan diukur dengan tiga parameter yaitu keaktifan mengikuti kegiatan untuk promosi hasil usahatani, memiliki waktu untuk mengikuti kegiatan, dan memiliki kelebihan hasil panen untuk mengikuti kegiatan.Sebagian besar petani memberikan keterangan bahwa kegiatan peken carik jarang diadakan dan kurang intensif untuk disosialisasikansehingga petani tidak mengetahui waktu pasti pelaksanaan kegiatan peken carik.Berdasarkan data yang diperoleh, sebanyak 50 (83\%) responden dari jumlah keseluruhan responden tidak aktif terlibat pada kegiatan peken carik sebabtidak mengetahui waktu pasti pelaksanaan kegiatan peken cariksehingga tidak dapat menyisihkannya secara sengaja untuk dijual pada kegiatan tersebut. Keterangan lainnya yaitu responden tidak memiliki waktu luang pada saat kegiatan diadakan karena memiliki aktivitas lain diluar aktivitas berusahatani, dan sebagian besar responden yang tidak mengetahui waktu pasti pelaksanaan kegiatan peken carik telah menjual seluruh sayur-mayurnya ke pasar sehingga tidak dapat mempromosikan sayur-mayur secara langsung kepada masyarakat. 


\subsection{Hubungan Motivasi Petani dalam Berusahatani Sayur-mayur dengan Keterlibatannya pada Kegiatan Peken Carik di Subak Sembung, Kelurahan Peguyangan, Kecamatan Denpasar Utara}

Menganalisis hubungan motivasi petani dalam berusahatani sayur-mayur dengan keterlibatannya padakegiatan peken carik di Subak Sembung, Kelurahan Peguyangan, Kecamatan Denpasar Utaramenggunakan analisis korelasi rank Spearmandengan bantuan program SPSS.Hasil analisis korelasimotivasi petani yang mencakup motivasi intrinsik dan motivasi ekstrinsik yang mempengaruhi keterlibatan petani yang diukur dari frekuensi mengikuti kegiatan dapat dilihat pada Tabel 4.

\section{Tabel 4.}

Analisis Hubungan Motivasi Petani dalam Berusahatani Sayur-mayur dengan

Keterlibatannya pada Kegiatan Peken Carik di Subak Sembung, Kelurahan Peguyangan, Kecamatan Denpasar Utara, Tahun 2018

\begin{tabular}{clcc}
\hline \multirow{2}{*}{ No. } & \multirow{2}{*}{ Motivasi Petani } & \multicolumn{2}{c}{ Keterlibatan Petani } \\
\cline { 3 - 4 } & & rs & sig \\
\hline 1. & Motivasi intrinsik & $0,291^{*}$ & 0,024 \\
2. & Motivasi ekstrinsik & $0,276^{*}$ & 0,033 \\
\hline
\end{tabular}

Sumber: Data primer diolah, 2018

Keterangan

$\mathrm{S}(*) \quad$ : Signifikan dengan tingkat kepercayaan $=0,05$

Tabel 4 menunjukkan bahwa bahwa antara motivasi intrinsik dan motivasi ekstrinsik petani dalam berusahatani sayur-mayur yang dihubungkan dengan keterlibatan petani pada kegiatan peken carik masing-masing memiliki nilai rs $\neq$ 0.Pengujian hipotesis dilakukan dengan membanding $r$ hitung dengan $r$ tabel dimana hasil yang didapatkan menunjukkan bahwa $r$ hitung $>r$ tabel $(0,254)$. Berdasarkan hal tersebut, diambil keputusan bahwa hipotesis yang diterima adalah adanya hubungan antara motivasi petani dalam berusahatani sayur-mayur dengan keterlibatannya pada kegiatan peken carik di Subak Sembung (Ha diterima dan Ho ditolak).

Berdasarkan data tersebut, motivasi intrinsik petani dalam berusahatani sayurmayur dengan keterlibatannya pada kegiatan peken carik memiliki hubungan yang signifikan dengan besar signifikansi $0,024<0,05$ pada taraf kepercayaan $5 \%$. Hasil analisis juga menunjukkan koefisien korelasinya sebesar 0,291, artinya korelasi antara motivasi intrinsik dengan keterlibatan petani berada pada interval koefisien 0,20 0,39sesuai tabel interpretasi koefisien korelasi menurut Sugiyono (2011), berarti memiliki hubungan yang rendah. Hubungan tersebut diperkuat dengan keterangan dari beberapa responden bahwa mereka mengikuti kegiatan peken carik untuk mencapai tujuan yang memotivasi mereka secara intrinsik dalam berusahatani sayur-mayur yaitu adanya penghargaan dan pengakuan oleh masyarakat secara luas akan kualitas sayurmayur yang mereka hasilkan, dan memperoleh tambahan penghasilan demi memenuhi kebutuhan hidup. Terlibatnya beberapa responden pada kegiatan peken carik untuk memperoleh pengakuan secara langsung akan kualitas sayur-mayur mereka dari para pengunjung serta mampu menjual sayur-mayur sebanyak-banyaknya di luar pemasaran mereka ke pasar. Berdasarkan hasil analisis, kekuatan hubungan yang rendah antara motivasi intrinsik dalam berusahatani sayur-mayur dengan keterlibatannya pada kegiatan peken carik dikarenakan rendahnya tingkat keterlibatan petani pada kegiatan 
tersebut akibat kurangnya sosialisasi kepada petani serta jarang diadakannya kegiatan peken carik.

Berdasarkan data tersebut, juga diketahui antara motivasi ekstrinsik petani dalam berusahatani sayur-mayur dengan keterlibatannya pada kegiatan peken carik memiliki hubungan yang signifikan dengan besar signifikansi $0,033<0,05$ pada taraf kepercayaan 5\%. Hasil analisis juga menunjukkan koefisien korelasinya sebesar 0,276, artinya korelasi antara motivasi ekstrinsik dengan keterlibatan petani berada pada interval koefisien 0,20-0,39sesuai tabel interpretasi koefisien korelasi menurut Sugiyono (2011) yang memiliki tingkat hubungan rendah. Hubungan tersebut diperkuat dengan keterangan dari beberapa responden bahwa motivasi ekstrinsik tertinggi petani salah satunya berasal dari pengunjung subak yaitu masyarakat sebagai pengguna fasilitas jogging track dan instansi tertentuyang datang berkunjung dan mengadakan kegiatan di subak. Mayoritas responden memberikan keterangan bahwa setiap kali kegiatan diadakan, ada beberapa responden yang terlibat pada kegiatan tersebut. Beberapa responden yang terlibat pada kegiatan peken carik dapat menawarkan sayurmayurnya secara langsung kepada pengguna fasilitas jogging track di luar pengunjung subak yang memang sengaja datang pada kegiatan peken carik dan dibantu oleh beberapa pihak instansi yang berpartisipasi pada penyelenggaraan kegiatan peken carik untuk turut mempromosikan. Petani yang terlibat pada kegiatan tersebut ingin mendapat pengakuan secara langsung dari masyarakat dan mencari eksistensi atas sayur-mayur yang mereka hasilkan.Berdasarkan hasil analisis, kekuatan hubungan yang rendah antara motivasi ekstrinsik dalam berusahatani sayur-mayur dengan keterlibatannya pada kegiatan peken carik dikarenakanrendahnya tingkat keterlibatan petani pada kegiatan tersebut akibatkurang disosialisasikan kepada petani serta jarang diadakannya kegiatan peken carik.

\section{Simpulan dan Saran}

\subsection{Simpulan}

Hasil dari penelitian ini secara umum mengenai motivasi petani dalam berusahatani sayur-mayur meliputi motivasi intrinsik dan motivasi ekstrinsik yang termasuk kategori tinggi, sedangkan tingkat keterlibatan petani pada kegiatan peken carikyang dilihat dari frekuensi mengikuti kegiatan termasuk kategori sangat rendah.Hubunganmotivasi petani dalam berusahatani sayur-mayur dengan keterlibatannya pada kegiatan peken carik di Subak Sembung, Kelurahan Peguyangan, Kecamatan Denpasar Utara memiliki hubungan yang signifikan.

\subsection{Saran}

Saran yang dapat diajukan terkait penelitian ini sebagai berikut.

1. Pengelola ekowisata yang mengorganisasikan program penunjang yaitu kegiatan peken carik diharapkan mampu meningkatkan frekuensi penyelenggaraan kegiatan secara berkala sehingga petani memiliki kesempatan besar untuk memperoleh tambahan penghasilan dan mendapat pengakuan secara langsung dari masyarakat akan kualitas sayur-mayur yang dihasilkan.

2. Pengelola ekowisata diharapkan lebih intensif melakukan sosialisasi kepada para petani jika akan mengadakan kegiatan peken carik sehingga petani tahu dan dapat terlibat pada kegiatan tersebut. Sosialisasi dapat berupa pemasangan spanduk di balai subak maupun pengumuman langsung saat rapat subak. 
3. Kegiatan peken carik juga mampu dikemas menarik oleh pengelola ekowisata dengan beberapa kali mengadakan kegiatan yang dapat menarik minat berkunjung masyarakat seperti kegiatan belajar bertani yangdipandu oleh para petani, mengadakan lomba-lomba bertema pertanian, dan demo pembuatan produk olahan dari sayur-mayur.

\section{Ucapan Terima Kasih}

Ucapan terimakasih penulis tujukan kepadaPekaseh Subak Sembung yaitu I Wayan Sunarta dan seluruhanggota subak yang telah membantu kelancaran penelitian ini.

\section{Daftar Pustaka}

Badan Pusat Statistik Provinsi Bali. 2017. Produksi (ton) Sayuran di Kota Denpasar Tahun 2012-2016. Internet.[Artikel_Online]. http://www.bali.bps.go.id/. Diakses tanggal 18 Januari 2018.

Hanafile, R. 2010. Pengantar Ilmu Ekonomi Pertanian. Edisi Pertama. Yogyakarta: Andi.

Manyamsari, Ira. 2014. Karakteristik Petani dan Hubungannya dengan Kompetensi Petani Lahan Sempit (Kasus di Desa Sinar Sari, Kecamatan Dramaga, Kabupaten Bogor, Jawa Barat).Internet.[Jurnal_online].http://www.jurnal.unsyiah.ac.id.Diunduh tanggal 19 Juli 2018.

Marsadi, Edy.2010. Analisis Pendapatan Beberapa Usahatani Sayuran Daun Di Kabupaten Pidie. Internet.[Jurnal_online].http://ejournal.unigha.ac.id.Diunduh tanggal 19 Januari 2018.

Padila. 2013. Keperawatan Gerontik. Yogyakarta: Nuha Medika.

Perdana, Ratno Putra. 2016. Analisis Perbedaan Pendapatan Petani Kakao yang Menerapkan Teknik Fermentasi dan yang Tidak Menerapkan Teknik Fermentasi Onembute Kabupaten Konawe.Internet.[Jurnal_online].http://sitedi.uho.ac.id.Diunduh tanggal 19 Juli 2018.

Restutiningsih.2016. Motivasi Petani dalam Berusahatani Hortikultura di Desa Wisata Candi Kuning, Kecamatan Baturiti, Kabupaten Tabanan.[Skripsi]. Program Studi Agribisnis Fakultas Pertanian Universitas Udayana. Denpasar.

Retno, Sri Kuning. 2010. Motivasi Petani dalam BudidayaTanaman Mendong (Fimbristylis Globulosa) di Kecamatan Minggir Kabupaten Sleman.Internet.[Jurnal_online].https://eprints.uns.ac.id. Diunduh tanggal 18 November 2017.

Sugiyono. 2011. Metode Penelitian Kuantitatif, Kualitatif dan R\&D. Bandung: Alfabeta.

Susilowati, Sri H. 2012. Luas Lahan Usaha Tani dan Kesejateraan Petani: Eksistensi Petani Gurem dan Urgensi Kebijakan Reforma Agraria. Internet.[Jurnal_online].http://ejurnal.litbang.pertanian.go.id. Diunduh tanggal 18 Juli 2018.

Winardi. 2002. Motivasi dan Pemotivasian dalam Manajemen. Jakarta: PT. Raja Grafindo. 